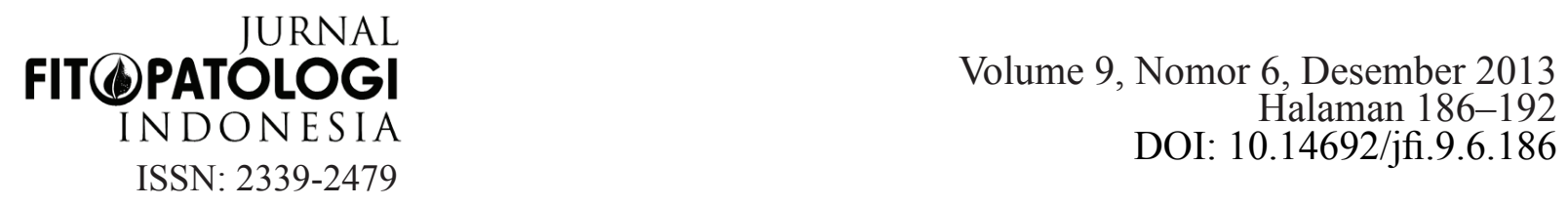

\title{
Patogenisitas Virus Tungro pada Varietas Tetua Padi Tahan Tungro
}

\section{Pathogenicity of Tungro Viruses in Parental Rice Varieties Resistant to Tungro}

\author{
R Heru Praptana ${ }^{1 *}$, YB Sumardiyono ${ }^{2}$, Sedyo Hartono ${ }^{2}$, Y Andi Trisyono ${ }^{2}$ \\ ${ }^{1}$ Loka Penelitian Penyakit Tungro, Sulawesi Selatan 91651 \\ ${ }^{2}$ Universitas Gadjah Mada, Yogyakarta 55281
}

\begin{abstract}
ABSTRAK
Tungro merupakan salah satu penyakit penting pada padi yang menjadi kendala dalam peningkatan produksi padi di Indonesia. Tungro disebabkan oleh infeksi Rice tungro bacilliform virus (RTBV) dan Rice tungro spherical virus (RTSV) yang ditularkan oleh wereng hijau Nephotettix virescens. Indikasi adanya variasi virulensi virus tungro dari daerah yang berbeda serta hubungan spesifik antara ketahanan varietas dan isolat virus tungro memerlukan kajian patogenisitas virus tungro dari beberapa daerah endemis di Indonesia. Penelitian ini bertujuan mendeterminasi patogenisitas virus tungro pada beberapa varietas tetua tahan tungro. Satu varietas rentan TN1 dan sepuluh varietas tetua tahan digunakan di dalam penelitian. Survei dan koleksi tanaman terinfeksi dilakukan di delapan daerah endemis tungro. Penularan buatan dengan metode tabung digunakan dalam patogenisitas virus tungro. Wereng hijau hasil tangkapan dari lapangan digunakan sebagai penular. Patogenisitas virus tungro diidentifikasi berdasarkan nilai insidensi dan indeks penyakit tungro. Hasil penelitian menunjukkan patogenisitas virus tungro dari beberapa daerah endemis bervariasi pada beberapa varietas tetua tahan. Isolat dari Jawa Tengah, Sulawesi tengah dan Nusa Tenggara Barat dapat menginfeksi semua varietas tetua tahan dan isolat Jawa Tengah memiliki patogenisitas tertinggi .
\end{abstract}

Kata kunci: endemis, ketahanan varietas, RTBV, RTSV, virulensi

\begin{abstract}
Tungro is one of the major diseases in rice which has become a constraint in increasing rice production in Indonesia. Tungro is caused by infection of two different viruses, i.e. Rice tungro bacilliform virus (RTBV) and Rice tungro spherical virus (RTSV), both of which can only be transmitted by green leafhoppers Nephotettix virescens (Distant) in a semipersistent manner. Since there is an indication of the existance of virulence variation of tungro viruses from different areas and the specific relationship between resistance of varieties and tungro viruses isolates, it is important to study the pathogenicity of tungro viruses from some endemic areas in Indonesia. This study aimed to identify the pathogenicity of tungro viruses from several endemic areas in Indonesia in some resistant varieties. One susceptible variety i.e. TN1 and ten resistant varieties were used in the study. Surveys and collection of infected plants and green leafhoppers were done in tungro endemic areas, namely West Java, Central Java, Yogyakarta, Central Sulawesi, West Sulawesi, South Sulawesi, Bali and West Nusa Tenggara. Artificial transmission using the test tube method was used in the pathogenicity test. Green leafhoppers caught from the field were used as transmitters.. The pathogenicity of tungro viruses were identified by the values of the incidence of tungro and the diseases indexes (DI). The result showed that difference in pathogenicity
\end{abstract}

\footnotetext{
*Alamat penulis korespondensi: Loka Penelitian Penyakit Tungro, Jalan Bulo No 101, Lanrang, Sidenreng Rappang, Sulawesi Selatan 91651
}

Tel: 0421-93702, Faks: 0421-93701, Surel: herujuly@yahoo.com 
of tungro viruses in some resistant varieties was observed. Isolates from Central Java, Central Sulawesi and West Nusa Tenggara were able to infect all of resistant varieties and the pathogenicity of Central Java isolate was the highest among the other isolates.

Key words: endemic, resistance of varieties, RTBV, RTSV, virulence

\section{PENDAHULUAN}

Tungro merupakan salah satu penyakit penting padi yang menjadi kendala dalam peningkatan produksi padi nasional. Tungro disebabkan oleh infeksi dua virus yang berbeda, yaitu Rice tungro bacilliform virus (RTBV) dan Rice tungro spherical virus (RTSV), yang keduanya hanya dapat ditularkan oleh wereng hijau (vektor) secara semipersisten. Hingga saat ini tungro masih terjadi di beberapa daerah, seperti Sumatera Barat, Jawa Barat, Jawa Tengah, Nusa Tenggara Barat, Bali, Sulawesi Barat dan Sulawesi Tengah. Penyebaran tungro tidak hanya di Indonesia, tetapi juga terjadi di India (Muralidharan et al. 2003), Malaysia, Filipina (Cabunagan et al. 2003), Thailand (Tangkananond et al. 2005), dan Vietnam (Du et al. 2005; Du et al. 2007). Di Indonesia, rerata luasan serangan tungro dalam kurun waktu tahun 2001-2006 mencapai 3650 ha per tahun. Pada musim tanam (MT) 2010/2011 terjadi serangan seluas 5828 ha dan meningkat menjadi 7177 ha pada MT 2011 yang tersebar di 33 provinsi (Kusprayogie et al. 2011).

Tiga komponen utama dalam pengendalian tungro ialah penggunaan varietas tahan dan tanam serempak, eradikasi sumber inokulum, dan keputusan dalam pemilihan varietas dan pengaturan waktu tanam.

Penggunaan varietas tahan merupakan komponen pengendalian tungro yang ramah lingkungan serta sesuai dan mudah diterima oleh petani karena tidak memerlukan biaya tambahan. Suatu varietas tahan tidak dianjurkan untuk ditanam secara terus-menerus karena dapat meningkatkan tekanan seleksi vektor dan memungkinkan untuk terbentuknya biotipe vektor baru.

Selama ini kejadian tungro sering ditemukan pada varietas yang sama di beberapa daerah yang secara geografi berbeda. Informasi variasi patogenisitas virus tungro dari berbagai daerah endemis di Indonesia sangat diperlukan untuk mengetahui sebaran virus tungro berdasarkan virulensinya. Keragaman RTBV dan RTSV di berbagai daerah endemis merupakan informasi yang sangat penting untuk menentukan strategi pengendalian kaitannya dengan penggunaan varietas tahan (Druka dan Hull 2010; Sharma et al. 2011). Interaksi patogen dengan ketahanan varietas merupakan dasar utama dalam penyusunan strategi pengelolaan varietas tahan di suatu wilayah untuk mencegah terjadinya epidemi penyakit yang ditimbulkannya (Papaix et al. 2011). Oleh karenaitu, karakterisasi keragaman patogenisitas virus tungro dari berbagai daerah endemis di Indonesia diperlukan. Tujuan penelitian ini ialah mendeterminasi variasi patogenisitas virus tungro dari beberapa daerah endemis di Indonesia pada beberapa varietas tetua tahan tungro.

\section{BAHAN DAN METODE}

\section{Persiapan Tanaman}

Benih padi dari 10 varietas tahan (Utri Merah 16680, Utri Merah 16682, Utri Rajapan, ARC 10312, ARC 10343, ARC 11554, ARC 12596, TKM 6, Tjempo Kidjik, dan Seratus Hari) dan satu varietas rentan (TN1 sebagai tanaman indikator karena mudah menunjukkan gejala tungro) disemai dalam pot kemudian dimasukkan ke dalam kurungan kasa dan dipelihara di rumah kaca. Setelah bibit berumur 21 hari maka bibit siap dibawa ke setiap daerah endemis.

\section{Lokasi Pengambilan Sampel}

Koleksi sampel wereng hijau dan tanaman terinfeksi virus tungro dilakukan di delapan daerah endemis tungro di Indonesia, yaitu Subang (Jawa Barat), Magelang (Jawa Tengah), Sleman (Daerah Istimewa 
Yogyakarta), Tabanan (Bali), Lombok Tengah (Nusa Tenggara Barat), Sidrap (Sulawesi Selatan), Polewali Mandar (Sulawesi Barat) dan Donggala (Sulawesi Tengah). Di setiap daerah endemis ditentukan empat lokasi pengamatan dengan jarak antarlokasi kurang lebih $200 \mathrm{~m}$.

\section{Uji Patogenisitas Virus Tungro}

Uji patogenisitas virus tungro dilakukan melalui penularan buatan terhadap bibit padi di dalam tabung gelas. Virus tungro ditularkan menggunakan wereng hijau dan sumber inokulum dari pertanaman terserang yang dikoleksi di setiap daerah endemis. Isolat virus tungro dan wereng hijau yang digunakan benar-benar telah berinteraksi di dalam kondisi lingkungan dan agroekosistem setempat sehingga kemurniannya dapat terjaga.

Wereng hijau hasil tangkapan dari setiap lokasi, satu per satu dimasukkan ke dalam kurungan yang sebelumnya telah diisi dengan rumpun tanaman terinfeksi (bergejala tungro) yang diperoleh dari pertanaman terserang. Setelah kurang lebih 5 jam, wereng hijau diinfestasikan pada setiap bibit varietas di dalam tabung gelas yang telah diisi air setinggi $2 \mathrm{~cm}$, masing-masing 2 ekor imago. Penularan dilakukan terhadap 10 bibit setiap varietas di setiap lokasi (40 tabung per daerah). Setelah 24 jam penularan di dalam tabung reaksi, semua bibit setiap varietas ditanam pada pot kemudian dimasukkan ke dalam kurungan kasa dan dipelihara di dalam rumah kaca. Sepuluh bibit dari setiap varietas tanpa diinokulasi virus tungro juga ditanam dalam pot kemudian dimasukkan ke dalam kurungan kasa sebagai pembanding.

Pengamatan dilakukan terhadap insidensi dan tingkat keparahan gejala tungro ketika tanaman berumur 3 minggu setelah tanam (MST). Insidensi tungro merupakan persentase jumlah tanaman terserang (tanaman yang menunjukkan gejala tungro). Tingkat keparahan gejala tungro dievaluasi berdasarkan sistem skor sesuai dengan standard evaluation system for rice (SESR), yaitu sebagai berikut:

1 , tidak ada gejala serangan;

3 , tinggi tanaman lebih pendek $1-10 \%$, perubahan warna daun dari kuning ke kuning oranye tidak nyata;

5, tinggi tanaman lebih pendek 11-30\%, perubahan warna daun dari kuning ke kuning oranye tidak nyata;

7, tinggi tanaman lebih pendek $31-50 \%$, perubahan warna daun dari kuning ke kuning oranye nyata;

9 , tinggi tanaman lebih pendek $>50 \%$, perubahan warna daun dari kuning ke kuning oranye nyata.

Berdasarkan skor tingkat keparahan gejala tersebut, indeks penyakit dihitung dengan menggunakan rumus sebagai berikut:

$\mathrm{DI}=\frac{n(1)+n(3)+n(5)+n(7)+n(9)}{t n}$, dengan

$\mathrm{DI}$, disease index (indeks penyakit); n, jumlah tanaman yang menunjukkan nilai skor tertentu; tn, total tanaman yang diskor.

Tingkat keparahan gejala tungro ditentukan berdasarkan nilai DI. Semakin tinggi nilai DI maka gejala yang ditimbulkan menjadi semakin parah dan sebaliknya. Virulensi virus tungro ditentukan berdasarkan tingkat keparahan gejala pada varietas rentan TN1 (Cabauatan et al. 1995). Semakin tinggi nilai DI maka tingkat virulensi virus tersebut semakin tinggi dan sebaliknya.

\section{HASIL}

Semua isolat virus tungro dapat menginfeksi semua varietas tetua tahan yang diuji serta terdapat variasi insidensi tungro dan DI pada semua varietas berdasarkan jumlah individu tanaman yang menunjukkan gejala tungro serta skor keparahan gejala. Gejala tungro dapat dibuktikan karena terjadi perubahan warna daun dari hijau menjadi hijau kekuningan dan penurunan tinggi tanaman sekitar $1-10 \%$ jika dibandingkan dengan tanaman kontrol dari setiap varietas. Skor keparahan gejala per individu tanaman sebagian besar dengan nilai 1 dan 3, serta hanya beberapa individu tanaman dengan nilai 5 yang terjadi pada beberapa varietas. Insidensi tungro pada semua varietas berkisar antara $0 \%$ dan $70 \%$ dan DI antara 1.0\% dan 2.8\% (Tabel 1). 
Tabel 1 Insidensi dan indeks penyakit tungro pada beberapa varietas tahan yang diinokulasi beberapa isolat virus tungro

\begin{tabular}{|c|c|c|c|c|c|c|c|c|c|c|c|}
\hline \multirow{2}{*}{$\begin{array}{l}\text { Isolat } \\
\text { Virus } \\
\text { Tungro }\end{array}$} & \multicolumn{11}{|c|}{ Insidensi Tungro (DI) } \\
\hline & $\begin{array}{c}\text { UM } \\
16680\end{array}$ & $\begin{array}{c}\text { UM } \\
16682\end{array}$ & UR & $\begin{array}{c}\text { ARC } \\
10312 \\
\end{array}$ & $\begin{array}{c}\text { ARC } \\
10343 \\
\end{array}$ & $\begin{array}{c}\text { ARC } \\
11554 \\
\end{array}$ & $\begin{array}{c}\text { ARC } \\
12596 \\
\end{array}$ & TKM 6 & TK & SH & TN1 \\
\hline Jabar & $10(1.2)$ & $0(1.0)$ & $0(1.0)$ & $20(1.4)$ & $10(1.2)$ & $0(1.0)$ & $0(1.0)$ & $0(1.0)$ & $0(1.0)$ & $20(1.4)$ & $90(7.2)$ \\
\hline Jateng & $30(2.0)$ & $40(2.0)$ & $40(1.8)$ & $50(2.2)$ & $50(2.4)$ & $40(1.8)$ & $20(1.4)$ & $30(1.6)$ & $50(2.0)$ & $70(2.8)$ & $100(9.0)$ \\
\hline DIY & $0(1.0)$ & $0(1.0)$ & $0(1.0)$ & $0(1.0)$ & $0(1.0)$ & $0(1.0)$ & $0(1.0)$ & $0(1.0)$ & $0(1.0)$ & $10(1.2)$ & $70(6.4)$ \\
\hline Sulteng & $40(1.8)$ & $20(1.6)$ & $30(1.6)$ & $70(2.6)$ & $40(1.8)$ & $30(1.6)$ & $40(1.8)$ & $40(2.0)$ & $30(1.6)$ & $60(2.4)$ & $100(7.9)$ \\
\hline Sulbar & $0(1.0)$ & $0(1.0)$ & $0(1.0)$ & $10(1.2)$ & $0(1.0)$ & $0(1.0)$ & $0(1.0)$ & $10(1.2)$ & $0(1.0)$ & $20(1.4)$ & $70(7.4)$ \\
\hline Sulsel & $0(1.0)$ & $10(1.2)$ & $10(1.2)$ & $20(1.4)$ & $10(1.2)$ & $0(1.0)$ & $0(1.0)$ & $10(1.2)$ & $0(1.0)$ & $20(1.4)$ & $100(6.4)$ \\
\hline Bali & $10(1.2)$ & $0(1.0)$ & $20(1.4)$ & $30(1.6)$ & $20(1.4)$ & $0(1.0)$ & $20(1.4)$ & $20(1.4)$ & $20(1.4)$ & $30(1.6)$ & $100(7.0)$ \\
\hline NTB & $20(1.4)$ & $20(1.4)$ & $20(1.4)$ & $30(1.6)$ & $40(1.8)$ & $20(1.4)$ & $20(1.4)$ & $10(1.2)$ & $30(1.6)$ & $50(2.0)$ & $90(6.9)$ \\
\hline Kontrol & $0(1.0)$ & $0(1.0)$ & $0(1.0)$ & $0(1.0)$ & $0(1.0)$ & $0(1.0)$ & $0(1.0)$ & $0(1.0)$ & $0(1.0)$ & $0(1.0)$ & $0(1.0)$ \\
\hline
\end{tabular}

Data di luar tanda kurung merupakan nilai insidensi tungro dengan satuan \%; Data di dalam tanda kurung merupakan nilai DI; UM, Utri Merah; UR, Utri Rajapan; TK, Tjempo Kidjik; dan SH, Seratus Hari; TN, Tani Nusantara

Setiap isolat virus tungro dapat menginfeksi serta menimbulkan insidensi tungro dan DI dengan nilai yang sama atau berbeda pada beberapa varietas. Hal tersebut menunjukkan adanya persamaan dan perbedaan kemampuan menginfeksi dari beberapa isolat virus tungro terhadap suatu varietas. Insidensi tungro $\geq$ $50 \%$ terjadi pada beberapa varietas yang terinfeksi oleh isolat Jateng, Sulteng, dan NTB, dengan nilai DI yang dihasilkan masih di bawah 3 karena skor gejala pada setiap individu tanaman yang terinfeksi bernilai maksimal 3. Namun demikian, semua varietas tergolong tahan terhadap semua isolat virus tungro berdasarkan rentang nilai DI. Kriteria ketahanan terhadap virus tungro digolongkan berdasarkan rentang nilai DI sesuai dengan SESR dengan kategori tahan (1-3), moderat (4-6), dan rentan (7-9).

Berdasarkan pengamatan insidensi tungro diketahui isolat Jateng, Sulteng, dan NTB mampu menginfeksi semua varietas, sedangkan isolat yang lain hanya mampu menginfeksi satu atau beberapa varietas tertentu. Isolat DIY hanya mampu menginfeksi varietas $\mathrm{SH}$ dan hanya varietas tersebut yang dapat diinfeksi oleh semua isolat. Isolat Jateng dan Sulteng menimbulkan insidensi tungro dan DI yang lebih tinggi daripada isolat yang lain. Terlihat bahwa isolat Jateng dan Sulteng lebih virulen dibandingkan dengan isolat yang lain pada tanaman TN1. Dengan demikian, isolat tersebut mampu menginfeksi serta menimbulkan insidensi tungro dan DI yang lebih tinggi daripada varietas tertentu. Isolat Bali dan NTB mampu menginfeksi lebih banyak varietas daripada isolat Jabar, DIY, Sulbar, dan Sulsel. Hal tersebut menunjukkan bahwa masing-masing isolat mempunyai kemampuan menginfeksi sejumlah varietas tertentu dengan nilai insidensi tungro dan DI yang berbeda-beda.

\section{PEMBAHASAN}

Gejala tungro yang terjadi berupa daun berwarna kuning hingga oranye, beberapa helai daun muda terpelintir serta tanaman menjadi kerdil. Adanya beberapa jenis gejala tersebut mengindikasikan bahwa tanaman telah terinfeksi oleh kedua virus tungro. Tanaman yang terinfeksi kedua virus tungro menunjukkan gejala yang lebih parah dari pada tanaman yang hanya terinfeksi salah satu virus tungro (Cabauatan dan Hibino 1988). Hal tersebut menunjukkan bahwa vektor hasil tangkapan di pertanaman telah memperoleh dan berhasil menularkan virus tungro. Keberhasilan penularan dan timbulnya gejala khas tungro menunjukkan bahwa vektor telah membawa kedua virus tungro dan menularkannya pada tanaman. Vektor dapat memperoleh dan menularkan kedua virus tungro secara bersama-sama atau 
RTSV saja dan tidak dapat memperoleh dan menularkan RTBV jika tidak memperoleh RTSV sebelumnya (Choi et al. 2009).

Walaupun semua varietas tergolong tahan terhadap semua isolat virus tungro, namun berdasarkan besarnya nilai DI pada setiap varietas, mengindikasikan adanya variasi virulensi antar isolat virus tungro. Variasi juga terlihat pada keparahan gejala tungro pada setiap individu tanaman dalam varietas yang sama, yang diinokulasi virus dan menggunakan vektor yang sama. Diduga bahwa terdapat variasi konsentrasi virus tungro dari setiap individu vektor baik virus yang diperoleh pada saat periode akuisisi maupun virus yang berhasil ditularkan ke tanaman. Widiarta et al. (2004), juga telah melakukan uji penularan virus tungro isolat Jabar, Jateng, DIY, Jatim dan Bali menggunakan vektor koloni Subang pada lima varietas tahan tungro, yaitu Tukad Petanu, Tukad Unda, Tukad Balian, Kalimas dan Bondoyudo, yang menunjukkan adanya variasi patogenisitas antar isolat tersebut. Oleh karena itu, tidak semua varietas tahan dapat digunakan untuk mengendalikan tungro di semua daerah endemis namun harus disesuaikan dengan variasi virulensinya.

Kesesuaian varietas tahan terhadap virus tungro diidentifikasi berdasarkan nilai insidensi dan DI. Suatu varietas tahan dikatakan sesuai untuk mengendalikan virus tungro di suatu daerah endemis apabila nilai insidensi tungro sebesar $<50 \%$ dan DI $\leq 3$. Hasil penelitian menunjukkan bahwa tidak semua varietas sesuai dengan semua isolat virus tungro. Varietas UM 16680, UM 16682, UR, ARC 11554, ARC 12596 dan TKM 6 sesuai untuk semua isolat, sedangkan varietas yang lain hanya sesuai untuk beberapa isolat tertentu. Hasil tersebut berbeda dengan hasil uji kesesuaian varietas tahan melalui penularan buatan menggunakan vektor koloni Subang yang menunjukkan bahwa varietas UM, UR, Habiganj dan ARC sesuai untuk isolat Jabar, Jateng, Jatim dan Bali, namun ARC tidak sesuai untuk isolat DIY (Widiarta et al. 2004). Varietas UM 16680, UR, ARC 11544 dan Tukad Unda memberikan respons ketahanan yang sama setelah diinokulasi dengan isolat Sulsel, Sulbar, Sulteng dan Sultra menggunakan vektor koloni Sidrap sehingga ketiga varietas tersebut sesuai untuk keempat isolat (Praptana et al. 2008). Sepuluh varietas lokal asal NTB menunjukkan respons tahan setelah diinokulasi virus tungro isolat Sulsel walaupun beberapa varietas diantaranya dapat terinfeksi virus tungro isolat NTB (Praptana et al. 2005).

Adanya variasi insidensi tungro dan DI pada beberapa varietas uji akibat infeksi beberapa isolat virus tungro mengindikasikan adanya perbedaan tingkat patogenisitas virus tungro dan efisiensi penularan virus tungro oleh koloni wereng hijau. Beberapa varietas yang diinokulasi dengan isolat virus tungro tertentu menggunakan koloni vektor yang berbeda dapat menghasilkan respons yang sama atau berbeda jika diinokulasi dengan beberapa isolat virus tungro menggunakan koloni vektor dari daerah asal isolat masingmasing. Demikian juga dengan penularan beberapa isolat virus tungro pada satu atau lebih varietas menggunakan koloni vektor yang sama maka dapat menghasilkan respons yang sama atau berbeda. Beberapa varietas dapat memberikan respons ketahanan yang sama terhadap infeksi isolat virus tungro tertentu walaupun memiliki latar belakang gen ketahanan yang berbeda. Efisiensi penularan virus tungro dipengaruhi oleh spesies dan genotipe vektor (Choi et al. 2009). Koloni wereng hijau dari daerah endemis yang berbeda menunjukkan variasi efisiensi dalam menularkan virus tungro. Berdasarkan insidensi tungro, diketahui adanya variasi efisiensi dalam menularkan virus tungro antar koloni vektor dari Jabar, Jateng, DIY, Jatim, Bali, NTB dan Sulsel pada berbagai golongan varietas tahan dengan isolat Bogor sebagai sumber inokulum (Widiarta et al. 2004).

Tingkat ketahanan suatu varietas terhadap virus tungro dan virulensi virus tungro berpengaruh terhadap tingkat keparahan gejala tungro. Suatu varietas dikatakan sesuai untuk isolat virus tungro tertentu jika memberikan respons tahan terhadap infeksi isolat tersebut. Adanya indikasi bahwa terdapat variasi virulensi virus tungro 
dari beberapa daerah endemis di Indonesia maka diperlukan beberapa varietas tahan berdasarkan kesesuaiannya terhadap isolat virus tungro tertentu. Kesesuaian varietas tahan terhadap virus tungro mendukung usaha pengendalian tungro spesifik isolat (Widiarta et al. 2004). Diversifikasi varietas tahan dengan latar belakang genetik yang berbeda menjadi komponen penting dalam keberhasilan pengendalian suatu patogen yang berkelanjutan baik melalui pergiliran varietas ataupun penanaman multi-varietas tahan di suatu wilayah (Skelsey et al. 2005).

Perbaikan dan perakitan varietas tahan tungro menggunakan materi tetua tahan yang telah diketahui kesesuaiannya terhadap berbagai isolat virus tungro dari daerah endemis akan menghasilkan beberapa varietas tahan tungro spesifik isolat dengan latar belakang genetik yang berbeda (Praptana dan Muliadi 2013). Pengendalian tungro menggunakan beberapa varietas tahan dengan berbagai sumber gen ketahanan sesuai diterapkan di daerah endemis di Asia Tenggara (Azzam dan Chancellor 2002). Ketersediaan beberapa varietas tahan tungro dengan berbagai gen ketahanan mendukung program pergiliran varietas dalam pengendalian tungro, memperluas preferensi konsumen dan menjaga durabilitas ketahanan terhadap virus dan vektor. Salah satu hambatan dalam penggunaan varietas tahan adalah durabilitas ketahanan yang menurun akibat tekanan seleksi populasi dan variasi virulensi patogen (Fabre et al. 2012). Durabilitas ketahanan varietas menjadi perhatian penting dalam pengendalian penyakit sehingga pemilihan tetua sebagai sumber dan kombinasi gen ketahanan berdasarkan kesesuaian interaksi patogen dengan ketahanan varietas sangat diperlukan dalam strategi perakitan varietas tahan (Palloix et al. 2009; Zhang et al. 2009 ).

Patogenisitas virus tungro dari beberapa daerah endemis di Indonesia bervariasi pada beberapa varietas tetua tahan tungro. Isolat Jateng, Sulteng dan NTB mampu menginfeksi semua varietas dan patogenisitas isolat Jateng paling tinggi dibanding isolat yang lain. Patogenisitas virus terhadap setiap varietas tahan di suatu wilayah perlu dipantau secara berkala karena ada indikasi terjadinya perubahan tingkat patogenisitas yang ditunjukkan dengan suatu varietas yang sebelumnya tahan menjadi tidak tahan (Janzac et al. 2009). Varietas UM 16680, UM 16682, UR, ARC 11554, ARC 12596 dan TKM 6 dapat digunakan sebagai materi tetua dalam perakitan varietas tahan yang sesuai untuk semua isolat virus tungro.

\section{UCAPAN TERIMA KASIH}

Penulis mengucapkan terima kasih kepada Sukanda (BB Padi Sukamandi), Arifan Sasongko (Diperta Kabupaten Magelang), Arvan (UNISA Palu), Abdi Negara (BPTP Sulteng), AANB. Kamandalu dan Nengah (BPTP Bali), serta Abdul Gaffar (BPTP NTB) atas bantuanya dalam survei dan pelaksanaan teknis di lapangan.

\section{DAFTAR PUSTAKA}

Azzam O, Chancellor TCB. 2002. The biology, epidemiology and management of rice tungro disease in Asia. Plant Dis. 86:88100. DOI: http://dx.doi.org/10.1094/ PDIS.2002.86.2.88.

Cabauatan PQ, Hibino H. 1988. Isolation, purification and serology of rice tungro bacilliform and rice tungro spherical viruses. Plant Dis. 72:526-528. DOI: http://dx.doi.org/10.1094/PD-72-0526.

Cabauatan PQ, Cabunagan RC, Koganezawa H. 1995. Biological variants of rice tungro viruses in the Philippines. Phytopathology. 85(1):77-81. DOI: http://dx.doi.org/10. 1094/Phyto-85-77.

Cabunagan RC, Sandig E, Pamplona A, Choi R. 2003. Use of resistant varieties in the management of rice tungro disease in Iloilo [Philippines]. J Trop Plant Pathol. 39(1 \& 2):78-79.

Choi IR, Cabauatan PQ, Cabunagan RC. 2009. Rice Tungro Disease. Rice Fact Sheet, IRRI, Sep. 2009: 1-4.

Du PV, Cabunagan RC, Choi IR. 2005. Rice "yellowing syndrome" in Mekong river delta. Omonrice. 13:135-138. 
Du PV, Cabunagan RC, Cabauatan PQ, Choi HS, Choi IR, Chien HV, Huan NH. 2007. Yellowing syndrome of rice etiology, current statuse and future challenges. Omonrice. 15:94-101.

Druka A, Hull R. 2010. Variation of rice tungro viruses: further evidence of two rice tungro bacilliform virus strains and possibly several rice tungro spherical virus variants. J Phytopathol. 146(4):175-178. DOI: http:// dx.doi.org/10.1111/j.1439-0434.1998. tb04675.x.

Fabre F, Rousseau E, Mailleret L, Moury B. 2012. Durable strategies to deploy plant resistance in agricultural landscapes. New Phytol. 193(4):1064-1075. DOI: http://dx.doi.org/10.1111/j.14698137.2011.04019.x.

Janzac B, Fabre F, Palloix A, Moury B. 2009. Constraints on evolution of virus avirulence factors predict the durability of corresponding plant resistances. Mol Plant Pathol. 10(5):599-610. DOI: http://dx.doi. org/10.1111/j.1364-3703.2009.00554.x.

Kusprayogie Y, Nuzulullia U, Gabriel DR. 2011. Prakiraan Serangan OPT Utama Padi pada MT 2011/2012. Buletin Peramalan OPT. 11(2): Ed ke- 8.

Muralidharan K, Krishnaveni D, Rajarajeswari NVL, PrasadASR. 2003. Tungro epidemics and yield losses in paddy fields in India. Current Sci. 85(8):1143-1147.

Palloix A, Ayme V, Moury B. 2009. Durability of plant major resistance genes to pathogens depends on the genetic background, experimental evidence and consequences for breeding strategies. New Phytologist. 183:190-199. DOI: http://dx.doi. org/10.1111/j.1469-8137.2009.02827.x.

Papaix J, Goyeau H, Cheyron PD, Monod H, Lannou C. 2011. Influence of cultivated landscape composition on variety resistance: an assessment based on wheat leaf rust epidemics. New Phytologist. 191:1095-1107. DOI: http://dx.doi. org/10.1111/j.1469-8137.2011.03764.x.

Praptana RH, Muliadi A. 2005. Ketahanan Sepuluh Padi Lokal Nusa Tenggara Barat (NTB) terhadap Tungro. Di dalam:
Prosiding Seminar dan Pertemuan Tahunan PEI dan PFI Cab. Makassar dan HPTI Komda Sulsel; 2005 Nov 22; Makassar (ID): PEI, PFI Komda Sulsel. hlm 85-89.

Praptana RH, Fauziah TL, Muliadi A, Bastian A, Burhanuddin A. Kesesuaian Tetua Padi Tahan Virus Tungro. 2008. Di dalam: Prosiding Seminar Nasional Penyakit Tungro: Revitalisasi Strategi Pengendalian Penyakit Tungro Mendukung Upaya Peningkatan Produksi Beras Nasional; 2007 Sep 5-6; Makassar (ID): Puslitbangtan, Badan Litbang Pertanian. hlm 90-97.

Praptana H, Muliadi A. 2013. Durabilitas ketahanan varietas padi terhadap penyakit tungro. IPTEK Tanaman Pangan. 8(1):1-7.

Sharma S, Rabindran R, Robin S, Dasgupta I. 2011. Analysis of the complete DNA sequence of rice tungro bacilliform virus from southern India indicates it to be a product of recombination. Arch Virol. 156(12):2257-62. DOI:

Skelsey P, Rossing WAH, Kessel GJT, Powell J, van der Werf W. 2005. Influence of host diversity on development of epidemics: An evaluation and elaboration of mixture theory. Phytopathology. 95:328338. DOI: http://dx.doi.org/10.1094/ PHYTO-95-0328.

Tangkananond W, Chettanachit D, Boonnadee W. 2005. Isolation and Purification of Rice tungro virus. Thammasat Int. J Sci Tech. 10(1):6-18.

Widiarta IN, Burhanuddin A, Daradjat AA, Hasanuddin A. 2004. Status dan Program Penelitian Pengendalian Terpadu Penyakit Tungro. Di dalam: Prosiding Seminar Nasional Status Program Penelitian Tungro Mendukung Keberlanjutan Produksi Padi Nasional; 2004 Sep 7-8; Makassar (ID): Puslitbangtan, Badan Litbang Pertanian. hlm 61-89.

Zhang H, Li G, Li W, Song F. 2009. Transgenic strategies for improving rice disease resistance. Afr J Biotech. 8(9):1750-1757. 